\title{
EFFECT OF HYDROGEN ADDITION AT DIFFERENT LEVELS ON EMISSIONS AND PERFORMANCE OF A DIESEL ENGINE
}

\author{
Y. Karagöz ${ }^{1, *}$
}

\begin{abstract}
The ratio of diesel vehicles in vehicle park and also the number of diesel vehicles sharply increase in the world. Advantages of diesel engines can be stated as high efficiency, low fuel consumption etc., on the other hand high amount of oxides of nitrogen caused by high compression ratio of diesel engines should be noted as its disadvantage. Moreover, a high amount of smoke emission is formed due to combustion characteristics of diesel engines. Both NOx and smoke are really hazardous for the environment. Stringent emission regulations force diesel engines to exhaust less $\mathrm{NO}_{\mathrm{x}}$ and smoke emissions. Thus, diesel engines require advanced after treatment systems. The catalyst materials in after - treatment systems are really expensive. In this study, different levels of hydrogen $[0 \%, 40 \%$ and $75 \%$ ] on energy basis of total fuel were introduced into intake manifold of engine. Brake thermal efficiency of the engine improved with increasing percentage of hydrogen. $\mathrm{CO}$, THC and smoke emissions are significantly decreased by using hydrogen as additional fuel. Especially, a novel decrease on smoke emission [up to $70.7 \%$ ] is obtained. However, particularly during $75 \%$ hydrogen addition, the dramatic increase in $\mathrm{NO}_{\mathrm{x}}$ emissions could not be prevented.
\end{abstract}

Keywords: Cl Engine, Diesel, Hydrogen, NOx, Smoke, Performance, Emissions

\section{INTRODUCTION}

Increasing energy demand in the world, decreasing oil reserves, and stringent emission regulation on transportation stimulate researchers to use environment-friendly, clean and alternative fuels on vehicles. In white Paper Report which was published by European Union Commission, 60\% reduction in greenhouse gas emissions in 2050 is aimed [1]. Despite a lot of measures taken by the European Union, renewable energy consumption level could not reach target value between 2010 and 2011 [1]. As known, diesel engines have to be used in transportation sector at least in the near future, however they emit oxides of nitrogen and particulate matter [2-4]. According to Air Quality Report in Europe, $\mathrm{NO}_{\mathrm{x}}$ emission values are $42 \%$ higher than from limit values in emission measurement points in 2011 [1]. Moreover, the particulate matter emission values are $43 \%$ higher than limit points [1]. The after - treatment equipment prices are really high due to costs of catalyst materials. Consequently, some researchers start to use alternative fuels such as LPG, CNG, LNG, biogas, and ethanol [515]. Hydrogen is a conspicuous and promising alternative fuel in the world [15]. The battery capacity is insufficient, for this reason it is impossible to use electrical vehicle or hybrid vehicle in the near future [16]. Using alternative, clean gas fuels such as hydrogen in diesel engines may be a solution in this period [17].

Some researchers $[18,19]$ had studied hydrogen in homogenously filled compression ignition engines [HCCI], but because of combustion stability $r$ it is impossible to use them in the real world. Some researchers used hydrogen in spark ignition engines [20-23], however the problems such as power loss, combustion stability problems, backfiring etc. are observed.

Some researchers studied in Otto engines and used hydrogen and oxygen as supplementary fuel [24]. Also, Karagoz et al. [24] sent water into the engine and they found that the engine performance and emissions improved except for $\mathrm{NO}_{\mathrm{x}}$.

Some researchers worked with natural gas and hydrogen blends [25, 26]. Huang et al. [27] studied about cyclic variations in SI engine fuelled with different levels of natural gas and hydrogen blends. On the other hand, some researchers [28] studied about compressed bio gas-diesel fuel blend and they obtained that the emission values improved with gas fuel addition. 
Despite superior performance of diesel engines, they suffer from $\mathrm{NO}_{\mathrm{x}}$ and particulate matter emissions $[28,29]$. On the other hand, emission regulations force to use advanced after - treatment systems to limit $\mathrm{NO}_{\mathrm{x}}$ and particulate matter emissions but prices of after - treatment systems are expensive. Using alternative gas fuels like hydrogen in diesel engines will be an alternative to control emissions [17]. Hydrogen has $576^{\circ} \mathrm{C}$ inflammation temperature, for this reason it will be easily used in diesel engines with diesel fuel [31]. In order to ignite combustible mixture, an energy source is required [32]. Ikegami et al. [33] used glow-plugs to heat combustible mixture. Antunes et al. [31] heated intake air to ensure ignition stability.

Using pilot diesel fuel as ignition source and hydrogen port fuel injection is the most common and reliable method [34-36]. Since, high pressure direct hydrogen injectors take place in the market, direct hydrogen injector into the cylinder is not commercially possible. Also, continuous hydrogen injection is not reliable since backfiring, pre-ignition and other combustion problems in the engines may occur [2]. For this reason, injection of hydrogen using gas injectors and an electronic control unit is the most suitable method.

The works about using hydrogen in compression ignition engines are given below. Horng-Wen $\mathrm{Wu}$ and Zhan-Yi Wu [36] introduced $0 \%$ to $20 \%$ hydrogen on energy basis at 1800 rpm constant engine speed. According to their obtained results, the thermal efficiency, $\mathrm{CO}$ and soot improved with hydrogen addition. Pan et al. [35] experimentally studied on two stroke, supercharged MTU 12V diesel engine. They introduced $0 \mathrm{slpm}, 22 \mathrm{slpm}$ and $220 \mathrm{slpm}$ hydrogen versus engine loads. They obtained that $\mathrm{CO}$ and particulate matter emissions decrease with increasing amount of hydrogen. Bika et al. [17] studied on a supercharged, Volkswagen diesel engine at $1700 \mathrm{rpm}$ engine speed with $0 \%$ and $40 \%$ hydrogen addition and at different engine loads. They obtained that the $\mathrm{NO}_{\mathrm{x}}$ emissions unchanged, particulate matter emissions did not change. Miyamoto et al. [16] sent up to $16 \%$ hydrogen on volume basis in a diesel engine. They obtained that $\mathrm{NO}_{\mathrm{x}}$ emissions were decreased while $\mathrm{HC}$ emission did not change. Hosseini and Ahmadi [37] studied on a heavy duty type diesel engine using hydrogendiesel dual fuel and they found that the emissions of NOx, UHC, soot, $\mathrm{CO}$ and $\mathrm{CO} 2$ are reduced with hydrogen addition. Talibi et al. [38] studied diesel-hydrogen dual fuel using high EGR levels, and they found that particulate mass decreased up to $75 \%$.

Many studies have been done on hydrogen addition in compression ignition engines, but a few studies can be found about effect of different levels of hydrogen addition. Especially, effect of wide range of hydrogen energy fraction from $0 \%$ to $75 \%$ has not been investigated. For this reason, in this study different levels of hydrogen [0\%, $40 \%$ and $75 \%$ on energy basis] were experimentally investigated at $1300 \mathrm{rpm}$ engine speed at full [100\%] engine load.

\section{TESTING SET}

Schematic illustration of the testing set is given in Figure 1. A single cylinder, four stroke, naturally aspirated engine was converted into common-rail diesel fuel system. Instead of mechanical injector, an alectromagnetic injecter was used. The pulverization angle as $145^{\circ}$ is same for both injectors. A high pressure diesel fuel pump and rail were used. $10^{8} \mathrm{~Pa}$ rail pressure was used as constant during tests. Diesel fuel is suitable for EN590 standart. A high pressure hydrogen tank was placed outside of the laboratory. The hydrogen has a purtiy of 99.99\%. An ECU was developed to control both hydrogen injector and diesel injector. A miniature oval gear type flow meter was installed to measure diesel fuel. A mass flow meter was installed on hydrogen line. Thermocouples were installed to measure engine cooling water temperature, engine oil temperature and exhaust gas temperature. A usb type NI6215 data acquisition card was used and using LabView software an interface was developed to measure diesel flow rate, hydrogen flow rate, AVL Dicom 4000 emssion analyser and AVL 415S smoke meter.

\section{Diesel Engine and The Engine Dynomometer}

The technical specs of the diesel engine can be given as follows: single-cylinder, $1.16 \mathrm{~L}$, naturally aspirated, four-stroke, direct injection. The diesel engine was developed by Erin motor and Yildiz Technical University. An water cooling type Eddy current dynamometer which has $40 \mathrm{~kW}$ engine loading capacity was used to load test engine in Yildiz Technical University. The technical properties of diesel engine and engine dynamometer were shown in Table 1. According to technical specifications, the maximum power of the engine is $18 \mathrm{~kW}$ at $2700 \mathrm{rpm}$ engine speed. The test rig was adapted to operate the diesel engine with hydrogen as fuel 


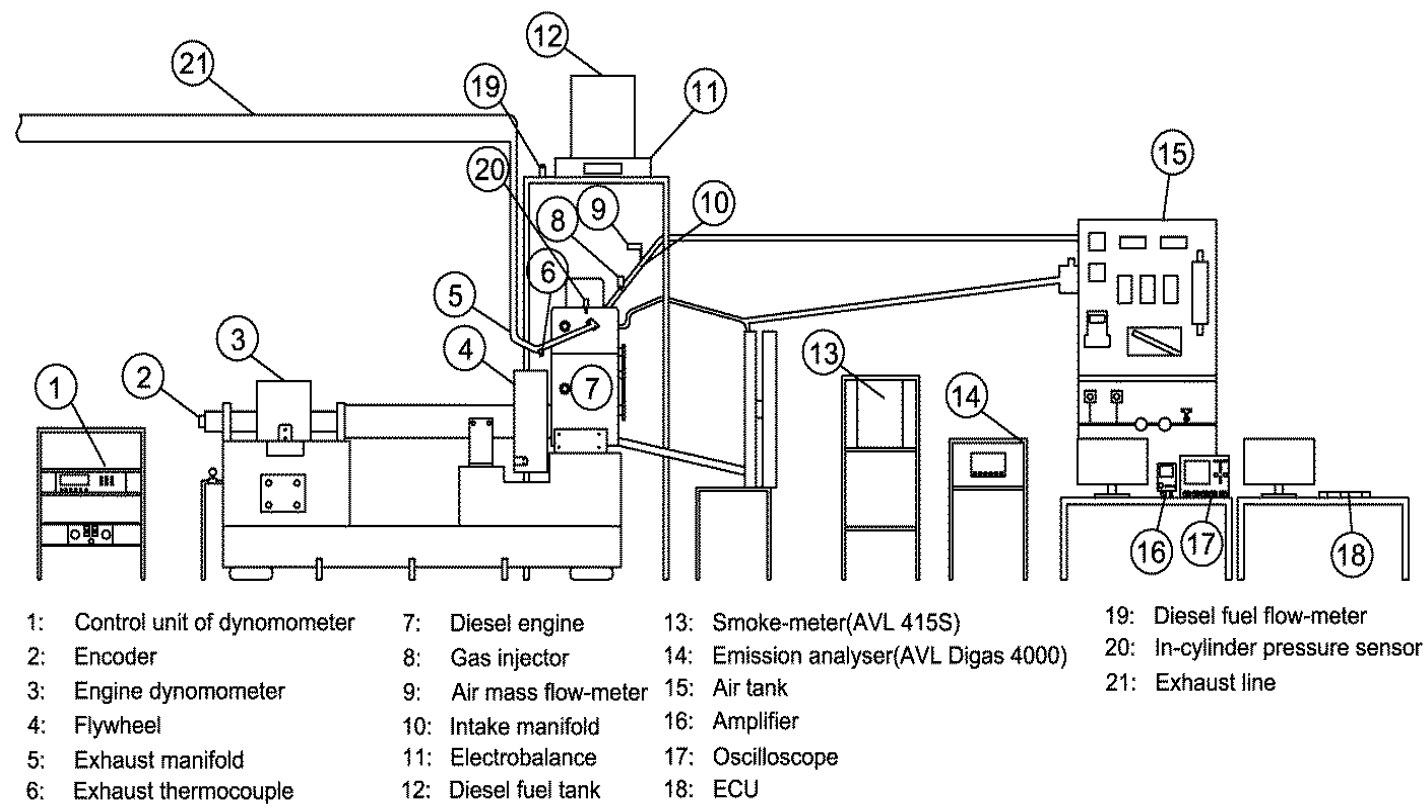

Figure 1. Schematics of the testing set

Table 1. Technical properties of the engine dyno and diesel engine

\begin{tabular}{ll}
\hline Engine manufacturer & Erin-motor engine \\
Aspiration & Natural \\
Maximum power & $18 \mathrm{~kW} @ 2700 \mathrm{rpm}$ \\
Number of cylinders & 1 \\
Bore $\times$ stroke $[\mathrm{mm}]$ & $108 \times 127$ \\
Cylinder volume $\left[\mathrm{cm}^{3}\right]$ & 1163 \\
Compression ratio & 14.7 \\
Speed range min-max [rpm] & $800-2700$ \\
Number of intake \& exhaust valves & $2 \& 2$ \\
Cooling & Water cooled \\
Dyno type \& power $[\mathrm{kW}]$ & Eddy current \& 40 \\
\hline
\end{tabular}

\section{Gas Fuel Line}

Hydrogen has unique properties. The auto-ignition temperature of hydrogen is $858 \mathrm{~K}$ [27]. The diffusion coefficient of hydrogen is $0.61 \mathrm{~cm} 2 / \mathrm{s}$ [27]. The adiabatic flame speed of hydrogen is $237 \mathrm{~cm} / \mathrm{s}$ [27]. Figure 2 shows schematics of hydrogen fuel line. A high pressure tank was used to store hydrogen which has purtiy above \%99.99. A double stage hydrogen pressure regulator was installed to reduce hyrogen pressure. To prevent backfire, a solenoid shut-off valve was used. A quick-connect type connection which operatesalso as a check valve is installed just before the diesel engine. Moreover, a relief-valve was installed to prevent overpressure on the line. A second pressure regulator which is line type regulator was set to accurately adjust the pressure line. An electromagnetic hydrogen gas injector was installed to the diesel engine manifold.

\section{The Engine Ecu}

Figure 3 shows the schematics of the engine ECU [electronic control unit]. The engine ECU was developed in Y1ldız Technical University and it operates with a microcontroller. The developed ECU can both control hydrogen injector and diesel injector. An incremental type encoder was installed on the engine. Two different signals one of which is zero signal determines piston position, and the other one generates 360 pulses/revolution were used to control injectors [diesel and hydrogen] with ECU. Arduino-Due cards were used to change injection advance and injection duration during the engine running. 12 Volt DC power supply was used 
during injectors were controlled. Since, the injection parameters directly affect the engine performance and emissions as proved by some reasearchers [39], using ECU to control injectors is very important. The diesel injection advance was adjusted to $28^{\circ}$ before top dead center.

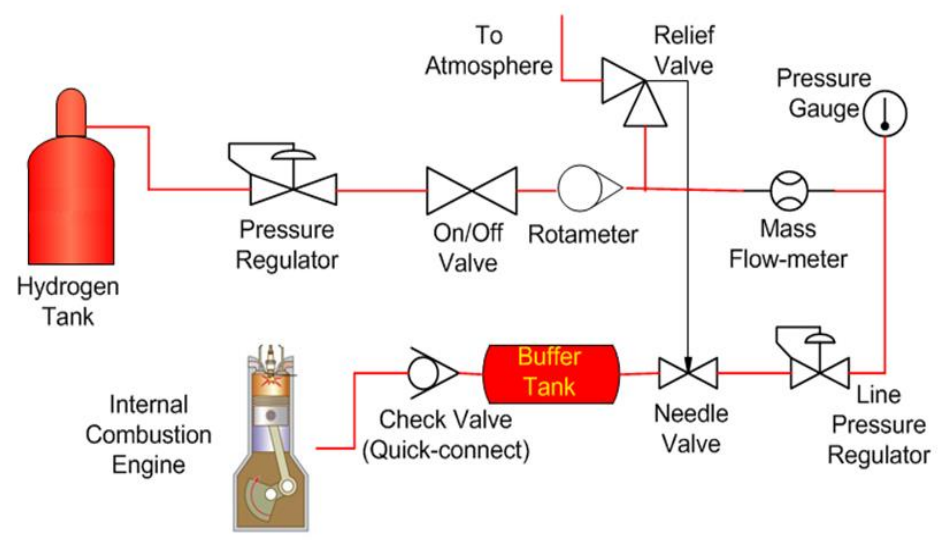

Figure 2. Schematics of the hydrogen line

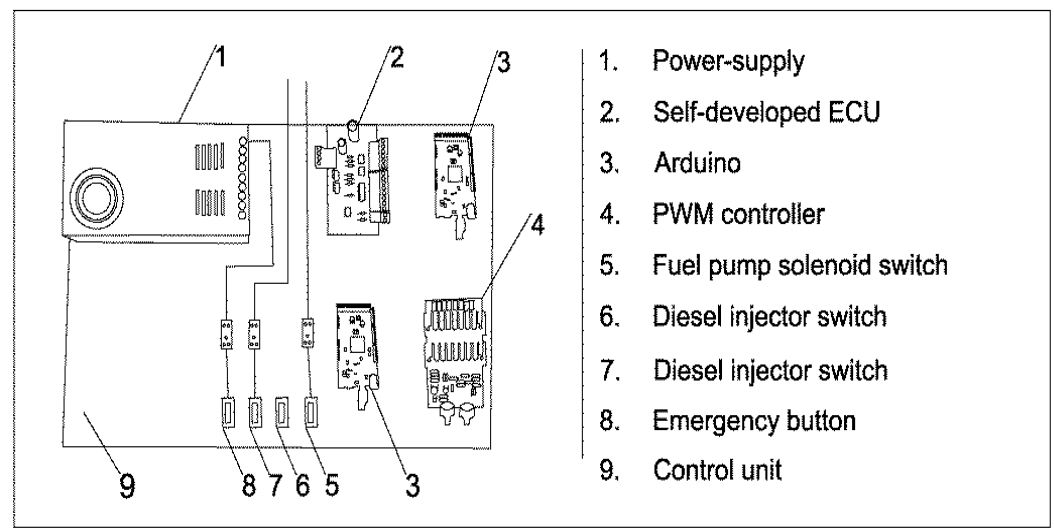

Figure 3. Schematics the engine ECU

\section{Exhaust Gas Emission Measurement}

Using AVL Digas 4000 exhaust analyser CO, THC and $\mathrm{NO}_{\mathrm{x}}$ emissions were measured. To measure smoke emission, AVL 415S smoke analyser was used. AVL Dicom 4000 measures CO and THC emissions as $\%$ volume, $\mathrm{NO}_{\mathrm{x}}$ emissions as ppm. AVL $415 \mathrm{~S}$ measures as FSN or $\mathrm{mg} / \mathrm{m}^{3}$. Since the engine torque and the engine speed are kept constant during test, the emission units were not converted into brake specific emissions.

\section{The Engine Operation}

The test engine was opareted according to ESC [European Stationary Cycle] at $1300 \mathrm{rpm}$ engine speed. $1300 \mathrm{rpm}$ is equal to A engine speed operation point for the test engine. Different levels of hydrogen energy fraction [0\%, $\% 40$ and $\% 75]$ were tested. $0 \%$ hydrogen energy level means neat diesel fuel operation. All tests were performed at full [100\%] engine load condition. The test engine is warmed up until it reaches the regime temperature. The diesel fuel injected at $28^{\circ}$ before top dead centre [BTDC]. The hydrogen fuel was injected at top dead centre [TDC]. The test conditions were given in Table 2. The engine brake torque was kept constant as $72 \mathrm{Nm}$ at $1300 \mathrm{rpm}$ engine speed. The engine brake power value is also constant as $9.8 \mathrm{~kW}$ in all hydrogen energy values. The brake specific fuel consumption, THC, $\mathrm{CO}, \mathrm{NO}_{\mathrm{x}}$ and smoke values are experimentally investigated with different values of hydrogen addition at $72 \mathrm{Nm}$ brake engine torque and $1300 \mathrm{rpm}$ engine speed. During experimental tests, any combustion problem like knock, backfiiring, preignition did not occur. The accuracies and uncertainty values are given in Table 3. 
Journal of Thermal Engineering, Research Article, Vol. 4, No. 2, Special Issue 7, pp. 1780-1790, February, 2018

Table 2. The summary of test conditions.

\begin{tabular}{llllll}
\hline $\begin{array}{l}\text { Engine brake } \\
\text { torque }\end{array}$ & Engine speed & $\begin{array}{l}\text { Start of } \\
\text { injection }\end{array}$ & $\begin{array}{l}\text { diesel } \\
\text { fraction }\end{array}$ & $\begin{array}{l}\text { Hydrogen } \\
\text { energy }\end{array}$ & $\begin{array}{l}\text { Diesel } \\
\text { fraction }\end{array}$ \\
\hline $72 \mathrm{Nm}$ & $1300 \mathrm{rpm}$ & $28^{\circ} \mathrm{BTDC}$ & $0 \%$ & $100 \%$ \\
$72 \mathrm{Nm}$ & $1300 \mathrm{rpm}$ & $28^{\circ} \mathrm{BTDC}$ & $40 \%$ & $60 \%$ \\
$72 \mathrm{Nm}$ & $1300 \mathrm{rpm}$ & $28^{\circ} \mathrm{BTDC}$ & $75 \%$ & $25 \%$ \\
\hline
\end{tabular}

Table 3. Measurement accuracies and calculated uncertainities

\begin{tabular}{|c|c|c|}
\hline Parameter & Device & Accuracy \\
\hline Engine torque & Load cell & $\pm 0.05 \mathrm{Nm}$ \\
\hline \multirow[t]{2}{*}{ Engine speed } & Incremental & $\pm 5 \mathrm{rpm}$ \\
\hline & Encoder & \\
\hline Cylinder pressure & Kistler 6253C & $\pm 0.5 \%$ \\
\hline Diesel flow rate & Biotech VZS-005 & $\pm 1 \%$ [of reading] \\
\hline NG flow rate & New-Flow TMF & $\pm 1 \%$ [F.S.] \\
\hline $\mathrm{CO}$ & AVL DiCom 4000 & $0.01 \%$ Vol. \\
\hline THC & AVL DiCom 4000 & $1 \mathrm{ppm}$ \\
\hline $\mathrm{NO}_{\mathrm{x}}$ & AVL DiCom 4000 & $1 \mathrm{ppm}$ \\
\hline Smoke & AVL 415S & $0.4 \%$ Vol. \\
\hline Calculated results & & Uncertainty value \\
\hline Engine power & $\pm 0.28 \%$ & \\
\hline \multirow[t]{2}{*}{ Thermal efficiency } & \multicolumn{2}{|c|}{ $\pm 1.10 \div 1.43 \%$} \\
\hline & \multicolumn{2}{|c|}{$[0 \% \div 75 \%$ hydrogen $]$} \\
\hline
\end{tabular}

\section{RESULTS AND DISCUSSION}

In this study, the engine performance [brake thermal efficiency] and emissions [CO, $\mathrm{THC}, \mathrm{NO}_{\mathrm{x}}$ and smoke] were experimentaly tested at full engine load and $1300 \mathrm{rpm}$ constant engine speed. The test engine and test cell were modified to operate with hdyrogen. The hydrogen fuel was injected into the test engine intake manifold using gas injector. An electromagnetic diesel injector was used to send diesel fuel into the engine. A self developed hybrid ECU which controls both diesel and gas injectors was used to operate the engine in dual fuel mode. Different levels of hydrogen energy fraction [0\%, 40\% and 75\%] were tested.

The brake thermal efficieny means the proportion of the brake power and fuel energy consumption. It shows how much energy is converted into useful energy [40]. The obtained brake thermal efficieny values depending on hydrogen energy fraction were given in Figure 4. The brake thermal efficiency values were improved with increased level of hydrogen energy fraction. The brake thermal efficiency values are \%23.8, $\% 24.1$ and $\% 24.3$ when hydrogen level is $0 \%, 40 \%$ and $75 \%$, respectively. The improvement in brake thermal efficiency is $1.26 \%$ and $2.1 \%$, respectively according to neat diesel fuel operation with $40 \%$ and $\% 75$ hydrogen addition. The flame speed of hydrogen is faster than diesel. Moreover, the diffusion coefficient of hydrogen is higher than other fuels. The homogeneity of air-fuel mixture improves with hydrogen addition. Also, the combustion efficiency of combustible mixture increases due to high flane speed of hydrogen. Thus, the combustion process approaches to ideal constant volume combustion.

$\mathrm{CO}$ is a harmful emission and released from internal combustion engines and it is a conclusion of inefficient combustion of petrolueum based fuels [41]. The basic reason of $\mathrm{CO}$ emission is lack of oxygen during combustion. The effect of hydrogen addition on $\mathrm{CO}$ emission is shown in Figure 5. The $\mathrm{CO}$ emission values are $0.28 \%$ vol., $0.21 \%$ vol. and $0.11 \%$ vol., respectively with $0 \%, 40 \%$ and $75 \%$ hydrogen addition. 
Journal of Thermal Engineering, Research Article, Vol. 4, No. 2, Special Issue 7, pp. 1780-1790, February, 2018

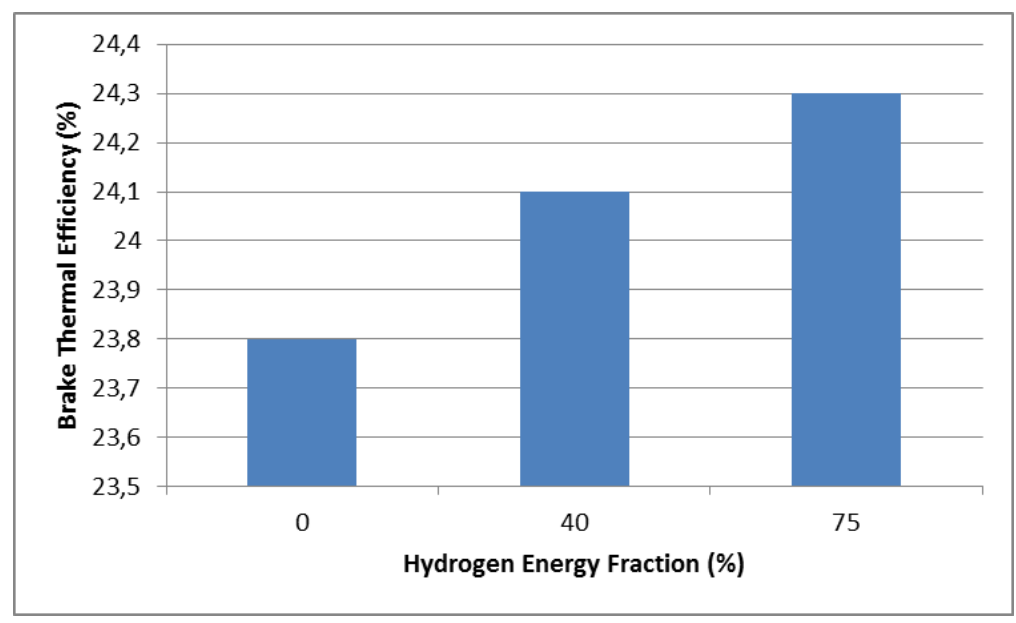

Figure 4. Effect of different amount of hydrogen addition on brake thermal efficiency

The improvement on CO emissions is $25 \%$ and $60.7 \%$ respectively, according to neat diesel with $40 \%$ and $75 \%$ hydrogen addition. The hydrogen fuel does not contain any carbon atom. On the other hand, the total carbon/hydrogen ratio decreases with increasing amount of hydrogen. Also, the combustion efficiency increases with hydrogen addition due to high flame speed and high diffusion coefficient properties of hydrogen.

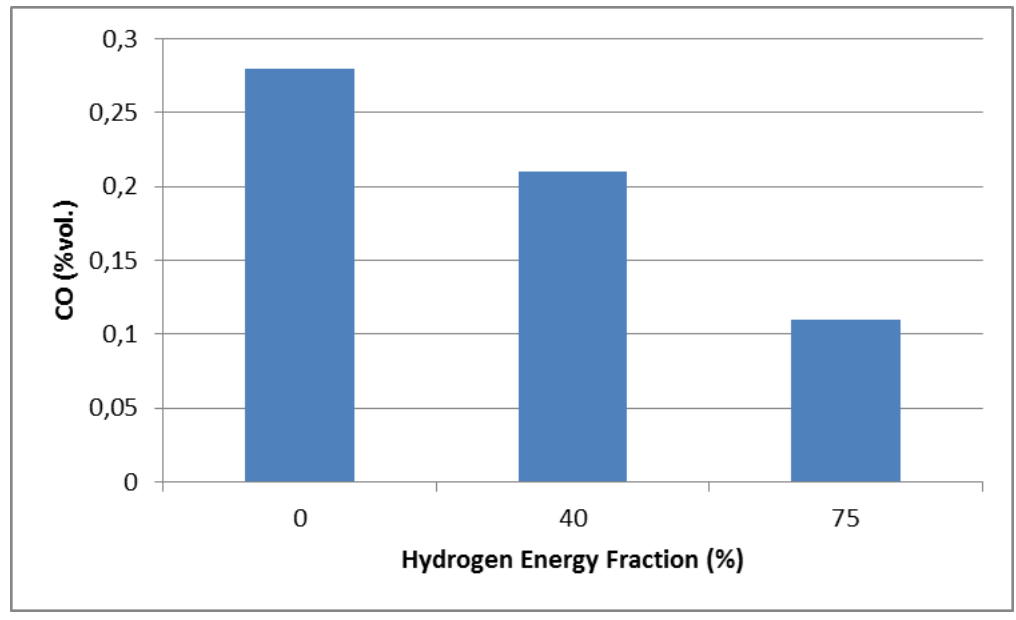

Figure 5. Effect of different amount of hydrogen addition on $\mathrm{CO}$ emissions

Hydrocarbons are generated from incomplete combustion of hydrocarbon based fuels. The exhausted unburned hydrocarbons from internal combustion engines is called as total hydrocarbons [THC] [42]. The total hydrocarbon values depending on different levels of hydrogen addition is given in Figure 6. The total hydrocarbon values are $23 \mathrm{ppm}, 16 \mathrm{ppm}$ and $8 \mathrm{ppm}$ with $0 \%, 40 \%$ and $75 \%$ hydrogen addition, respectively. The improvement in THC emission according to neat diesel fuel is $30.4 \%$ and $60.2 \%$ with $40 \%$ and $75 \%$ hydrogen addition respectively. Oxides of nitrogen $\left[\mathrm{NO}_{\mathrm{x}}\right]$ are composed of nitrogen monoxide $[\mathrm{NO}]$ and nitrogen dioxide $\left[\mathrm{NO}_{2}\right]$. The oxides of nitrogen are really harmful for the environment and human health. Two basic mechanisms explain nitrogen monoxide formation which are thermal mechanism [Zeldovich mechanism] and promt mechanism [Fenimore mechanism].

The NO formation depends on in-cylinder temperature and oxygen concentration. In the combustion process of compression ignition engines, thermal mechanism has a domination on oxides of nitrogen formation $[43,44]$. 


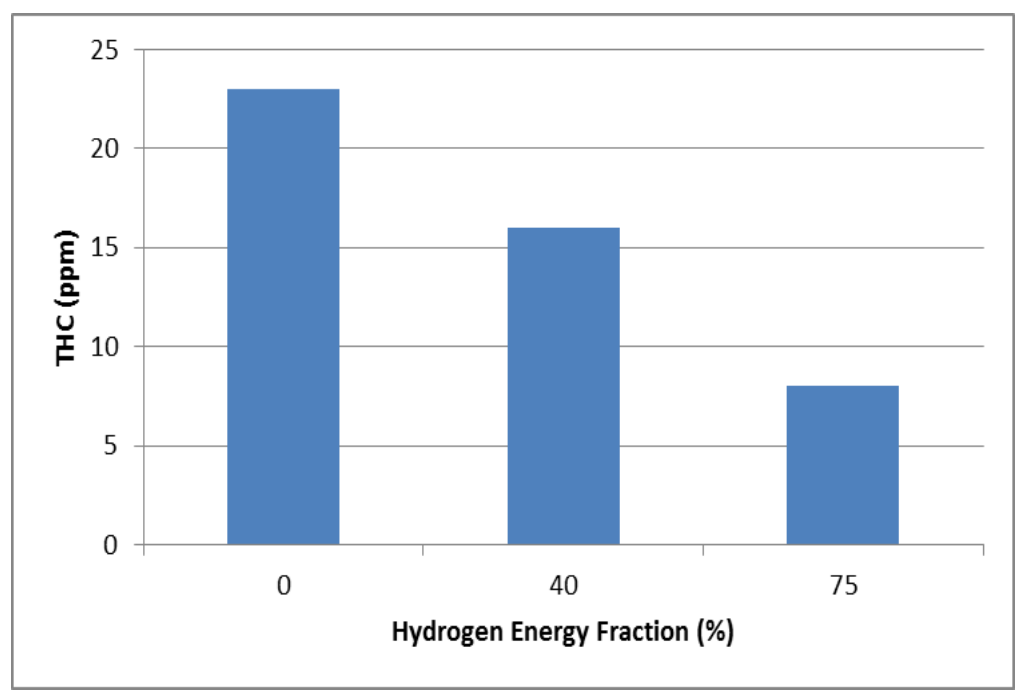

Figure 6. Effect of different amount of hydrogen addition on THC emission

Figure 7 shows the oxides of nitrogen emission values depending on different level of hydrogen addition. According to obtained results, the oxides of nitrogen emissions dramatically increase with hydrogen addition. The $\mathrm{NO}_{\mathrm{x}}$ values are $2740 \mathrm{ppm}, 2970 \mathrm{ppm}$ and $3970 \mathrm{ppm}$ with 0\%, 40\% and 75\% hydrogen addition. The increase in $\mathrm{NO}_{\mathrm{x}}$ emissions are $8.4 \%$ and $44.9 \%$, respectively with $40 \%$ and $75 \%$ hydrogen addition according to neat diesel. Since, aidabatic flame temperature is higher than other petroleum fuel, in-cylinder temperature increases with hydrogen addition. Also, high in-cylinder pressure increases with hydrogen addition due to high flame speed of hydrogen. Also, the combustion duration shortened with hydrogen addition. As a result, $\mathrm{NO}_{\mathrm{x}}$ emissions dramatically increase with hydrogen addition.

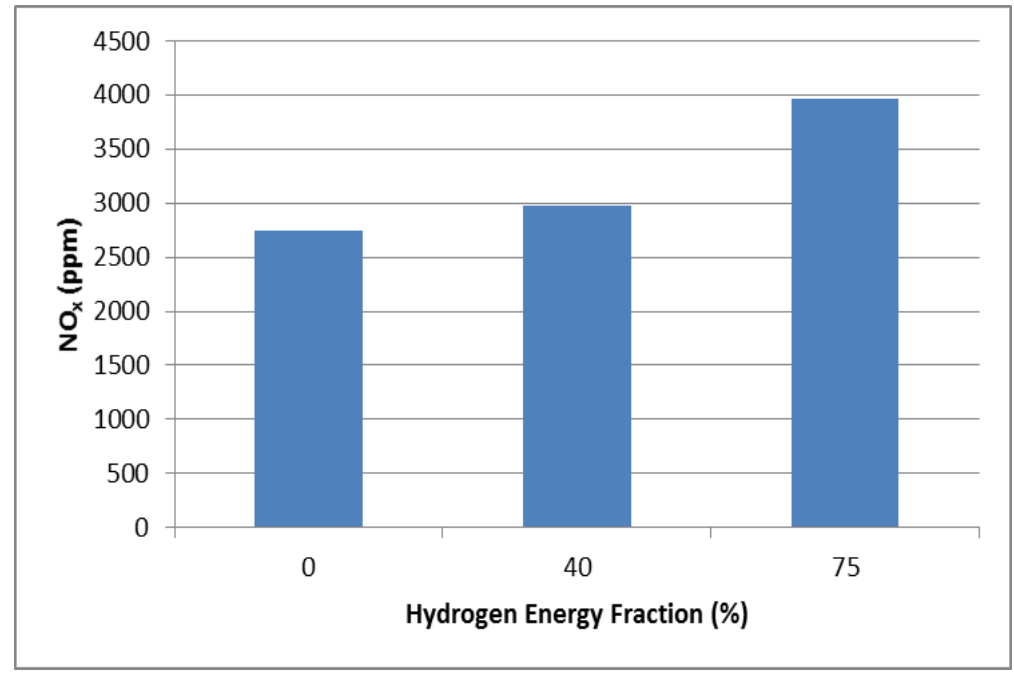

Figure 7. Effect of different amount of hydrogen addition on $\mathrm{NO}_{\mathrm{x}}$ emission

Diesel smoke emission is formed from carbonaceous materials. Carbonaceous materials are generated due to incomplete combustion and lack of oxygen [42]. Figure 8 shows smoke emission values depending on different level of hydrogen addition. The smoke emission values are 0.58 FSN, 0.47FSN and 0.17FSN with $0 \%$, $40 \%$ and $75 \%$ hydrogen addition, respectively. The improvement in smoke emission values is $18.9 \%$ and $70.7 \%$ regarding to neat diesel with $40 \%$ and $75 \%$ hydrogen addition, respectively. Hydrogen does not contain any carbon atoms. Moreover, it improves combustion efficiency. Furthermore, it improves the homogeneity of combustible mixture. Also, total carbon/hydrogen ratio of fuel will decrease with hydrogen fuel addition. Thus, smoke emission decreases with increasing amount of hydrogen fuel. 


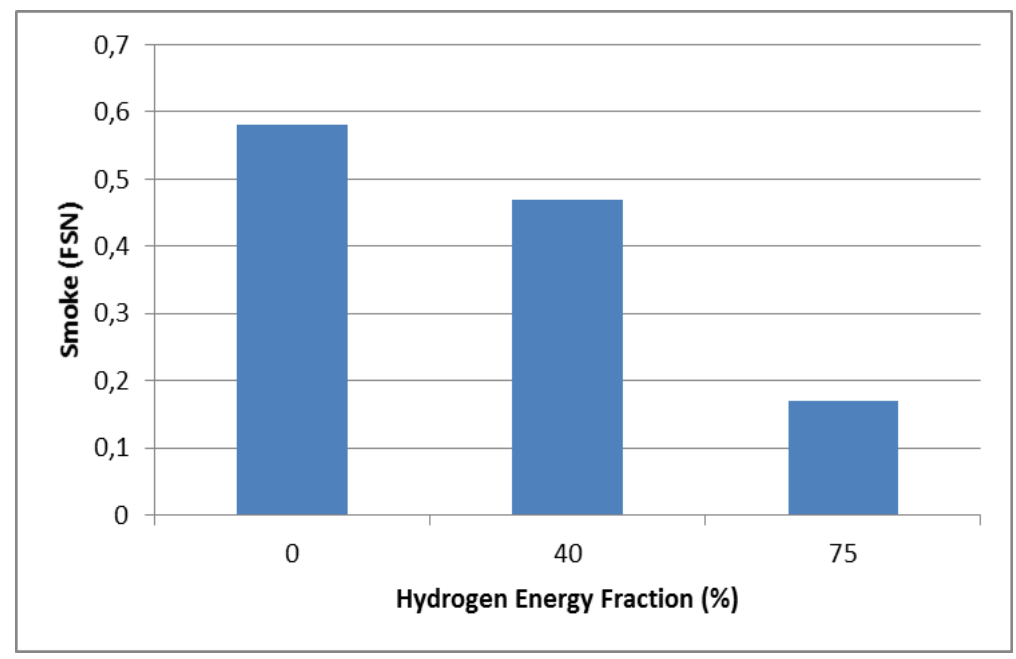

Figure 8. Effect of different amount of hydrogen addition on smoke emission

\section{CONCLUSION}

Engine values regarding brake thermal efficiency, and emissions of $\mathrm{CO}, \mathrm{THC}$, smoke and $\mathrm{NO}_{\mathrm{x}}$ were experimentaly investigated in this work. Tests were performed in a four stroke, water cooled, naturally aspirated, single cylinder diesel engine at $1300 \mathrm{rpm}$ constant engine speed and full engine load. Different levels of hydrogen $[0 \%, 40 \%$ and $75 \%$ by energy content] were experimentaly tested in the compression ignition test engine.

Acquired results are given below:

a. The brake thermal efficiency increased by $1.26 \%$ and $2.1 \%$, respectively with addition of $40 \%$ and $75 \%$ hydrogen compared to neat diesel fuel.

b. CO emissions decreased by $25 \%$ and $60.7 \%$, respectively with $40 \%$ and $75 \%$ hydrogen addition as energy content compared to only diesel fuel.

c. THC emissions improved bye $30.4 \%$ and $60.2 \%$ with $40 \%$ and $75 \%$ hydrogen addition.

d. A dramatic increase of $8.4 \%$ and $44.9 \%$ is obtained in $\mathrm{NO}_{\mathrm{x}}$ emissions respectively with $40 \%$ and $75 \%$ hydrogen addition compared to only diesel fuel.

e. A novel improvement of $18.9 \%$ and $70.7 \%$, respectively is observed in smoke emissions with $40 \%$ and $75 \%$ hydrogen addition.

\section{ACKNOWLEDGEMENT}

This research was supported by Tübitak (Scientific and Technological Research Council of Turkey) with 1512 project. Project Number: 2150175. The author is also indebted to Şahin Metal A.Ş. and Erin Motor for test apparatus and equipment donation.

\section{NOMENCLATURE}

$\begin{array}{ll}\mathrm{CI} & \text { Compression ignition } \\ \mathrm{CNG} & \text { Compressed natural gas } \\ \mathrm{CO} & \text { Carbon monoxide } \\ \mathrm{CO}_{2} & \text { Carbon dioxide } \\ \mathrm{DPF} & \text { Diesel particulate filter } \\ \mathrm{ECU} & \text { Electronic control unit } \\ \mathrm{HC} & \text { Hydrocarbons } \\ \mathrm{HCCI} & \text { Homogenous charge compression ignition } \\ \text { ICEs } & \text { Internal combustion engines } \\ \text { LNG } & \text { Liquefied natural gas } \\ \text { LPG } & \text { Liquefied petroleum gas } \\ \mathrm{NO}_{\mathrm{x}} & \text { Oxides of nitrogen }\end{array}$


SCR Selective catalytic reduction

SI Spark ignition

THC Total unburned hydrocarbons

USB Universal serial bus

\section{REFERENCES}

[1] European Environment Agency [EEA]. (2013). Trends and projections in Europe 2013: Tracking progress towards Europe's climate and energy targets until 2020. Report No 10/2013.

[2] Köse, H., Ciniviz, M. (2013). An experimental investigation of effect on diesel engine performance and exhaust emissions of addition at dual fuel mode of hydrogen. Fuel Processing Technology, 114, 26-34.

[3] Liu, Y., Yang, J., Sun, J., Zhu, A., Zhou, Q. A (2011). Phenomenological model for prediction auto-ignition and soot formation of turbulent diffusion combustion in a high pressure common rail diesel engine. International Journal of Hydrogen Energy, 4, 894-912.

[4] Nieminen, J., D'Souza, N., Dincer, I. (2010). Comparative combustion characteristics of gasoline and hydrogen fuelled ICEs. International Journal of Hydrogen Energy, 35, 5114-5123.

[5] Lata, D.B., Misra, A., Medhekar, S. (2012). Effect of hydrogen and LPG addition on the efficiency and emissions of a dual fuel diesel engine. International Journal of Hydrogen Energy, 37, 6084-6096.

[6] Lata, D.B., Misra, A., Medhekar, S. (2011). Investigations on the combustion parameters of a dual fuel diesel engine with hydrogen and LPG as secondary fuels. International Journal of Hydrogen Energy, 36, 13808-13819.

[7] He, Y., Mab, F., Deng, J., Shao, Y., Jian, X. (2012). Reducing the idle speed of an SI CNG engine fueled by HCNG with high hydrogen ratio. Int J Hydrogen Energy, 37, 8698-8703.

[8] Mohammed, S.E., Baharom, M.B., Aziz, A.R.A., Firmansyah. (2011). The effects of fuel-injection timing at medium injection pressure on the engine characteristics and emissions of a CNG-DI engine fueled by a small amount of hydrogen in CNG. International Journal of Hydrogen Energy, 36, 11997-12006.

[9] Xin, Z., Jian, X., Shizhuo, Z., Xiaosen, H., Jianhua, L. (2013). The experimental study on cyclic variation in a spark ignited engine fueled with biogas and hydrogen blends. International Journal of Hydrogen Energy, 38, 11164-11168.

[10] Park, C., Park, S., Lee, Y., Kim, C., Lee, S., Moriyoshi, Y. (2011). Performance and emission characteristics of a SI engine fueled by low calorific biogas blended with hydrogen. International Journal of Hydrogen Energy, $36,10080-88$.

[11] Greenwood, J.B., Erickson, P.A., Hwang, J., Jordan, E.A. (2014). Experimental results of hydrogen enrichment of ethanol in an ultra-lean internal combustion engine International Journal of Hydrogen Energy, 39, 12980-90.

[12] Ji, C., Liu, X., Wang, S., Gao, B., Yang, J. (2014). A laminar burning velocity correlation for combustion simulation of hydrogen-enriched ethanol engines. Fuel, 133, 139-142.

[13] Biffiger, H., Soltic, P. (2015). Effects of split port/direct injection of methane and hydrogen in a spark ignition engine. International Journal of Hydrogen Energy, 40, 1994-2003.

[14] Shivaprasad, K.V., Raviteja, S., Chitragar, P., Kumar, G.N. (2014). Experimental investigation of the effect of hydrogen addition on combustion performance and emissions characteristics of a spark ignition high speed gasoline engine. Procedia Technology, 14, 141-148.

[15] Saravanan, N., Nagarajan, G. (2009). Experimental investigation on performance and emission characteristics of dual fuel DI diesel engine with hydrogen fuel. SAE Paper No. 2009-26-032.

[16] Miyamoto, T., Mikami, M., Kojima, N., Kabashima, H., Urata, Y. (2009). Effect of hydrogen fraction in intake mixture on combustion and exhaust emission characteristics of a diesel engine. SAE Paper No. 2009-240086 .

[17] Bika, A.S., Franklin, L.M., Kittelson, D.B. (2008). Emissions effects of hydrogen as a supplemental fuel with diesel and biodiesel. SAE Paper No. 2008-01-0648.

[18] Gomes-Antunes, J.M., Mikalsen, R., Roskilly, (2008). A.P. An investigation f hydrogen fuelled HCCI engine performance and operation. International Journal of Hydrogen Energy, 33, 5823-5828.

[19] Szwaja, S., Grab-Rogalinski, K., (2009). Hydrogen combustion in a compression ignition diesel engine. International Journal of Hydrogen Energy, 34, 4413-4421. 
[20] Sopena, C., Dieguez, P.M., Sainz, D., Urroz, J.C., Guelbenzu, E., Gandia, L.M., (2010). Conversion of a commercial spark ignition engine to run on hydrogen: Performance comparison using hydrogen and gasoline. International Journal of Hydrogen Energy, 35, 1420-1429.

[21] Ji, C., Wang, S. (2009). Effect of hydrogen addition on the idle performance of a spark ignited gasoline engine at stoichiometric condition. International Journal of Hydrogen Energy, 34, 3546-3556.

[22] Wang, S., Ji, C., Zhang, M., Zhang, B. (2010). Reducing the idle speed of a spark-ignited gasoline engine with hydrogen addition. International Journal of Hydrogen Energy, 35 10580-88.

[23] Andrea, T.D., Henshaw, P.F., Ting, S.K. (2004). The addition of hydrogen to a gasoline fuelled SI engine. International Journal of Hydrogen Energy, 29, 1541-52.

[24] Karagöz, Y., Yüksek, L., Sandalc1, T., Dalkılıc, A.S. (2015). An experimental investigation on the performance characteristics of a hydroxygen enriched gasoline engine with water injection. International Journal of Hydrogen Energy, 40, 692-702.

[25] Hu, E., Huang, Z., Liu, B., Zheng, J., Gu, X., Huang B. (2009). Experimental investigation on performance and emissions of a spark-ignition engine fuelled with natural gas-hydrogen blends combined with EGR. I International Journal of Hydrogen Energy, 34, 528-539. [26] Hu, E., Huang, Z., Liu, B., Zheng, J., Gu, X. (2009). Experimental study on combustion characteristics of a spark-ignition engine fuelled with natural gas-hydrogen blends combining with EGR. International Journal of Hydrogen Energy, 34, 1035-1044.

[27] Huang, B., Hu, E., Huang, Z., Zheng, J., Liu, B., Jiang, D. (2009). Cycle-by-cycle variations in a spark ignition engine fueled with natural gas-hydrogen blends combined with EGR. International Journal of Hydrogen Energy, 34, 8405-8414.

[28] Köten, H., Yilmaz, M., Gül, M.Z. (2014). Compressed bio gas [CBG]-diesel dual fuel engine optimization study for ultra-low emission", JAME.

[29] Heywood, J.B. (1988). Internal Combustion Engine Fundamentals. McGraw Hill Inc. New York, USA.

[30] Miyamoto, T., Hasegawa, H., Mikami, M., Kojima, N., Kabashima, H., Urata, Y. (2011). Effect of hydrogen addition to intake gas on combustion and exhaust emission characteristics of a diesel engine. International Journal of Hydrogen Energy, 36, 13138-13149.

[31] Bose, P.K., Maji, D. (2009). An experimental investigation on engine performance and emissions of a single cylinder diesel engine using hydrogen as inducted fuel and diesel as injected fuel with exhaust gas recirculation. International Journal of Hydrogen Energy, 34, 4847- 4854.

[32] Gomes-Antunes, J.M., Mikalsen, R., Roskilly, A.P. (2009). An experimental study of a direct injection compression ignition hydrogen engine. International Journal of Hydrogen Energy, 34, 6516-6522.

[33] Ikegami, M., Miwa, M., Shioji, M. A (1982). Study on hydrogen fuelled compression ignition engines. International Journal of Hydrogen Energy, 7, 341-353.

[34] Christodoulou, F., Megaritis, A. (2013). Experimental investigation of the effects of separate hydrogen and nitrogen addition on the emissions and combustion of a diesel engine. International Journal of Hydrogen Energy, 38, 10126-10140.

[35] Pan, H., Pournazeri, S., Princevac, M., Miller, J.W., Mahalingam, S., Khan, M.Y., Jayaram, V., Welch, W.A. (2014). Effect of hydrogen addition on criteria and greenhouse gas emissions for a marine diesel engine. International Journal of Hydrogen Energy, 39, 11336-11345.

[36] Wu, H.W., Wu, Z.Y. (2012). Investigation on combustion characteristics and emissions of diesel/hydrogen mixtures by using energy-share method in a diesel engine. Applied Thermal Engineering, 42, 154-162.

[37] Hosseini, S.M., Ahmadi, R. (2017). Performance and emissions characteristics in the combustion of co-fuel diesel-hydrogen in a heavy duty engine. Applied Energy, 205, 911-925.

[38] Talibi, M., Hellier, P., Ladommatos, N. (2017). The effect of varying EGR and intake air boost on hydrogendiesel co-combustion in CI engines. International Journal of Hydrogen Energy, 42, 6369-6383.

[39] Köten, H., Yilmaz, M., Gül, M.Z. (2012). Effects of the injection parameters and compression ratio on the emissions of a heavy duty diesel engine. 147-163.

[40] Pulkrabek, W.W. (2004). Engineering Fundamentals of the Internal Combustion Engine, Prentice Hall.

[41] Wei, L., Geng, P. (2016). A review on natural gas/diesel dual fuel combustion, emissions and performance. Fuel Processing Technology 142, 264-278.

[42] Heywood, JB. (1988). Internal Combustion Engine Fundamentals; McGraw Hill Inc. New York, USA, 1988 . 
Journal of Thermal Engineering, Research Article, Vol. 4, No. 2, Special Issue 7, pp. 1780-1790, February, 2018

[43] Fenimore, CP. (1971). Formation of nitric oxide in premixed hydrocarbon flames, Symp Combust, 13(1):373-380.

[44] Stiesch, DIG. (2003). Modeling Engine Spray and Combustion Processes. Springer Berlin Heidelberg. 